УДК 82.09

Любецкая В. В., кандидат филологических наук, старший преподаватель кафедры языковой и общегуманитарной подготовки иностранцев, ИМО ОНУ имени И. И. Мечникова

\title{
ОБ ОСОБЕННОСТЯХ ВИДЕНИЯ В РОМАНЕ Ф. М. ДОСТОЕВСКОГО «ИДИОТ»
}

У запропонованій статті розглядається унікальний художній досвід Ф. М. Достоєвського у сфері зорового сприйняття світу, бачення, одухотвореного та олюдненого. Предметом художнього бачення письменника стає безпосереднє мислення (ідея). Роман «Ідіот» поліфонічний, з безліччю рівноправних свідомостей (голосів), щзо перебувають в єдності $i$ зберігають свою некупність. Крім иього, у даному творібагатогранне бачення. Болісне $i$ пристрасне, воно відкриває приховане $i$ потаємне в духовному, виразному модусі. Цілий світ, переломлений через свідомість кожного з героїв, суб 'єктивний, але набуває сенсу $і$ значення в своїй єдності.

Ключові слова: персоналізм, роман, поліфонія, бачення, світ, краса.

The proposed article considers the unique artistic experience of F. M. Dostoevsky in the sphere of visual perception of the world, a vision, which is spiritualized and humanized. The subject of the writer's artistic vision is immediate thinking (idea). The novel «Idiot» is polyphonic, with a multitude of equal consciousnesses (voices), staying in unity and preserving their non-merging. There is also a multifaceted vision in this work. Excruciating and passionate, it reveals the hidden and the inmost in the spiritual, expressive mode. The whole world, refracted through the consciousness of each of the heroes, is subjective, but acquires meaning and significance in its unity.

Key words: personalism, novel, polyphony, vision, peace, beauty.

В предложенной статье рассматривается уникальный художественный опыт Ф. М. Достоевского в сфере зрительного восприятия мира, видения, одухотворенного $u$ очеловеченного. Предметом художественного видения писателя становится непосредственное мышление (идея). Роман «Идиот» полифоничен, $c$ множеством равноправных сознаний (голосов), пребывающих в единстве и сохраняющих свою 
неслиянность. Кроме того, в данном произведении - многогранное видение. Мучительное и страстное, оно открывает сокрытое и сокровенное в духовном, выразительном модусе. Цельй мир, преломленный через сознание каждого из героев, субъективен, но приобретает смысл и значение в своем единстве.

Ключевые слова: персонализм, роман, полифония, видение, мир, красота.

Уникальная способность художника гениального - особое видение мира: «... писатель исторгает свой внутренний образ в литературном сознании, которое становится слепком его духовного мира» [Терц 2009:232]. Так гоголевская проза чрезвычайно поэтична в том числе благодаря своей визуальности, магии и мании зрительного чувства. Значительную роль играет визуальное восприятие в творчестве Л. Н. Толстого, И. А. Гончарова, И. С. Тургенева. Художественный опыт Ф. М. Достоевского иной, это «реализм в высшем смысле», который подает зрительные образы опосредованно, через восприятие героев, их глазами. По справедливому замечанию К. В. Мочульского, «мир природный и вещзный не имеет у Достоевского самостоятельного существования, он до конща очеловечен и одухотворен» [Мочульский 1995:363]. Можно сказать, что предметом художественного видения становится непосредственное мышление. «Художественное видение мысли» сделало Ф. М. Достоевского «великим художником идеи» [Бахтин 1972]. Романы Ф. М. Достоевского полифоничны (по М. М. Бахтину), то есть у писателя доминирует голос (точнее голоса), формирующие идеи и мировидение. Новый тип художественного мышления, открытие в области художественной формы - полифонический роман Ф. М. Достоевского: «Этот тип художественного мышления нашел свое выражение в романах Достоевского, но его значение выходит за пределы только романного творчества и касается некоторых основных принципов европейской эстетики. Можно даже сказать, что Достоевский создал как бы новую художественную модель мира, в которой многие из основных моментов старой художественной формы подверглись коренному преобразованию [Бахтин 1972]. Итак, «множественность самостоятельных и неслиянных голосов» есть подлинная полифония голосов полноченных: «Не множество характеров и судеб в едином 
объективном мире в свете единого авторского сознания развертываются в его произведениях, но именно множественность равноправных сознаний с их мирами сочетается здесь, сохраняя свою неслиянность, в единство некоторого события. Главнье герои Достоевского действительно в самом творческом замысле художника не только объекты авторского слова, но и субъекты собственного, непосредственно значащуего слова ... В этом смысле образ героя у Достоевского - не обычный объектный образ героя в традициионом романе» [Бахтин 1972].

С голосом у Ф. М. Достоевского связано зрительное восприятие видение, оно многогранно, калейдоскопично, и находится, как правило, внесистемно-монологической рамки единого мировоззрения. Мир Ф. М. Достоевского глубоко персоналистичен, «всякую мысль он воспринимает и изображает как позицию личности» [Бахтин 1972], поэтому зрительные образы у Ф. М. Достоевского важны не сами по себе, а в их духовном, выразительном модусе, существующие как факт в сознании героев писателя. Из этого следует, что вещный и внешний мир у писателя преломлен через сознание каждого из героев, оценивается крайне субъективно, но приобретает смысл и значение в своем единстве. Даже описание внешности героев строится у Ф. М. Достоевского иначе, чем психологические портреты, традиционные для критического реализма. Писатель не дает детального описания, визуальный образ персонажа представлен глазами других героев. В романе «Идиот» о невероятной красоте Настасьи Филипповны мы узнаем, благодаря видению иными героями ее образа (портрета): «Так это Настасья Филипповна? промолвил он, внимательно и любопьтно поглядев на портрет, - удивительно хороша! - прибавил он тотчас же с жаром. На портрете была изображена действительно необыкновенной красотыл женщцна. Она была сфотографирована в черном шелковом платье, чрезвычайно простого $u$ изящного фасона; волосы, по-видимому, темно-русые, были убраны просто, по-домашнему; глаза темные, глубокие, лоб задумчивый; выражение лица страстное и как бы высокомерное. Она была несколько худа лицом, может 
быmь, и бледна...» [Достоевский 1981:30]. Слова «удивительно хороша» с жаром произносит князь Мышкин, все остальное описание будничное, сдержанное, как будто автор угадывает черты своей героини, что можно заключить из следующих фраз: «волосы, по-видимому, темно-русые», «выражение лица страстное и как бы высокомерное», «она была несколько худа лицом, может быть, и бледна». Полнотой зрения автор не обладает, в «удивительной красоте» Настасьи Филипповны скрыта и маска, и лицо, и лик. Маски предназначены для разных героев (Гани, семьи Епанчиных и других «чужих», равнодушных людей), лицо и сияющую внешнюю красоту созерцает, и передает читателю свое впечатление, Рогожин, лик дано прозреть князю Мышкину, увидевшему закопченную икону в образе Настасьи Филипповны, застывшую, странно-страдающую красоту ее лица. Взгляд Рогожина направлен на поверхность, князь Мышкин смотрит в глубину. Два этих основных взгляда (и два голоса) единовременно присутствуют и значимы для понимания образа Настасьи Филипповны, а также и мира в романе в целом. Князь Мышкин обладает безграничным зрением, стирает все возможные границы и ограничения. Но и другие герои интересны своим зрительным восприятием действительности, интенсивным до неправдоподобия. Пропуская свои чувства через зрительный нерв, герои романа постигают мир через отдельные образы. Пристальное внимание мучительно и страстно, оно захватывает героя и читателя Ф. М. Достоевского и «стоит перед глазами» [Достоевский 1981:22]. Вспомним, что в случае с Настасьей Филипповной самозабвенное созерцание ее красоты достигает наибольшего эмоционального накала. Так для Рогожина самый первый взгляд на нее становится роковым: «Я тогда, князь ... через Невский перебегал, а она из магазина выходит, в карету садится. Так меня mym и прожгло» [Достоевский 1981:12]. В тот же вечер Рогожин спешит в театр преподнести подарок Настасье Филипповне, увидеть ее: «Я ... на час втихомолку сбегал и Настасью Филипповну опять видел; всю ту ночь не спал... Что у меня тогда под ногами, что предо мной, что по бокам - ничего я этого не знаю и не помню» [Достоевский 1981:13]. Для Рогожина все остальное 
перестает существовать в присутствии Настасьи Филипповны, она - предмет его безумной страсти. Но «пристальное вглядывание» в лица характерно не только для одного Рогожина. Князь глядит на портрет Настасьи Филипповны и пытается «разгадать что-то, скрывавшееся в этом лице и поразившее его давеча»: «Давешнее впечатление почти не оставляло его, и теперь он спешил как бы что-то вновь проверить. Это необыкновенное по своей красоте и ещзе по чему-то лицуо сильнее ещзе поразило его теперь. Как будто необъятная гордость и презрение, почти ненависть, были в этом лице, и в то же самое время что-то доверчивое, что-то удивительно простодушное ... Эта ослепляющая красота была даже невыносима ... странная красота» [Достоевский 1981:78]. Портрет (даже не сама героиня) не оставляет равнодушным никого: «Генеральша несколько времени, молча и с некоторым оттенком пренебрежения, рассматривала портрет Настасьи Филипповньл... Да, хорома, - проговорила она наконец, - очень даже ...Так вы такую-то красоту изените? - обратилась она вдруг к князю. - Да... такую... - отвечал князь с некоторым усилием. - То есть именно такую? - Именно такую. - 3 а что? - В этом лище... страдания много... - проговорил князь, как бы невольно ... - Экая сила! - вскричала вдруг Аделаида, жадно всматриваясь в портрет ... - Такая красота - сила, - горячо сказала Аделаида, - с этакой красотой можно мир перевернуть!» [Достоевский 1981:78]. Упорное молчание Аглаи, взглянувшей на портрет мельком и закусившей губы, красноречивое свидетельство того, что красота Настасьи Филипповны зацепила и уязвила ее самолюбие. При личной встрече с Настасьей Филипповной князь потерялся совершенно: «Князь снял запор, отворил дверь и-отступил в изумлении, весь даже вздрогнул: пред ним стояла Настасья Филипповна. Он тотчас узнал ее nо портрету...» [Достоевский 1981:99]. Князь тронут, поражен до того, что не может выговорить и слова, в дальнейшем он весь вечер смотрит в лицо героини пронизывающим и скорбным взглядом, сопереживая ей полностью и понимая ее как никто другой: «Я давеча ваш портрет увидал, и точно я знакомое лищо узнал. Мне тотчас показалось, что вы как будто звали меня...» 
[Достоевский 1981:163]. Удивительно, что зрение князя - область откровения, он видит суть каждого человека, происходит это вдруг и невольно, но поражает окружающих своей откровенностью, неуместностью, предельной искренностью, простотой. Вглядываясь в Аглаю, князь Мышкин видит и ее прекрасное лицо, но взгляд его «странен» для Аглаи, она производит совсем иное впечатление на князя и потому проигрывает Настасье Филипповне: «Иногда вдруг он начинал приглядываться к Аглае и по пяти минут не отрывался взглядом от ее лица; но взгляд его был слишком странен: казалось, он глядел на нее как на предмет, находящийся от него за две версты, или как бы на nортрет ее, а не на нее самое. - Что вы на меня так смотрите, князь? сказала она вдруг, прерывая веселый разговор и смех с окружающими. - Я вас боюсь; мне все кажется, что вы хотите протянуть вашу руку и дотронуться до моего лица пальцем, чтоб его пощупать. Не правда ли, Евгений Павлыч, он так cмотрит?» [Достоевский 1981:334]. Внимательно приглядевшись к отношениям, которые складываются у Настасьи Филипповны с князем Мышкиным и Рогожиным можно убедиться, что они совершенно особые. Это сложно назвать любовью или ненавистью, герои притягиваются друг к другу, они «закованы странной близостью», чувствуют друг друга на расстоянии, понимают друг друга без слов, угадывают незримое, пророчествуют, проецируют события до их реального воплощения. Данные герои воспринимают друг друга именно в свете своего видения, утверждая образ, запечатленный в их сознании. Созданный образ лишь частично равен образу реальному, что собственно и порождает непредсказуемость и фатальность таких непростых отношений. Настасье Филипповне предлагает руку князь, но она бежит от него (и от себя) к Рогожину. Рогожин, встретив у дома Настасьи Филипповны князя Мышкина, с которым он побратался и «уступил» свою возлюбленную, неожиданно решает его убить. Князь ради Настасьи Филипповны оставляет Аглаю, но она снова убегает из-под венца от князя к Рогожину. Все эти события обуславливают и трагическую развязку романа. Наиболее значительны и устойчивы видения князя. Неслучайно 
Ф. М. Достоевский проводит параллель между своим героем и «Дон Кихотом Ламанчским» Сервантеса (шутка Аглаи про Дон Кихота весьма показательна). Для Ф. М. Достоевского образ Дон Кихота был «всего законченнее из прекрасных лиц в литературе христианской» [Достоевский 2006]. Дон Кихот живет в своем мире, в видениях, навеянных ему чтением рыцарских романов. Воображаемый мир перемешивается с миром реальным (ветряные мельницы предстают великанами, стадо баранов - вражеским войском и т. д.) Мышление князя Мышкина близко образу мыслей Дон Кихота, что и является основополагающей чертой, формирующей жизненную философию героя и его видение жизни. Но князь не живет абсолютно в воображаемом мире, поэтому и не является человеком сумасшедшим, он скорее юродивый, хотя его и называют «идиотом», но прислушиваются к его мнению и духовно зависимы от него многие герои. В самом сокровенном исповедуются князю, просят и нуждаются в его участии. То есть существует незримая, обратная связь между князем и целым миром. Видение князя часто со знаком плюс или трагично по своей сути (он провидец и создатель событий одновременно), в то время как Рогожина - со знаком минус, и это тоже влияет на мир, на его гармонию и целостность. Однако творческая и пророческая сила воображения, видения «оказывается проклятием «князя Христа»: ему нельзя ничего предвидеть, ибо все исполняется по его подозрениям. Он несет ответственность за каждую свою мысль» [Назиров 2005:193]. Предвидеть и видеть в случае князя фактически синонимы. Так, например, он предвидит покушение Рогожина. Как только князь приезжает в Петербург «при выходе из вагона ... вдруг померещился странный, горячий взгляд чьих-то двух глаз», потом он спешит из Летнего сада единственно с тем, чтоб увидеть «давешние глаза»: «Да, это были те caмble глаза (и в том, что mе caмble, нет уже никакого теперь сомнения!), которые сверкнули на него утром, в толпе, когда он выходил из вагона Николаевской железной дороги; те самые (совершенно те самые!), взгляд которых он поймал потом давеча, у себя за плечами, садясь на стул у Рогожина. Рогожин давеча отрекся: он спросил с искривленной, леденящей улыбкой: «Чьи же это были 
глаза?» И князю ужасно захотелось подойти к Рогожину и сказать ему, «чьи это были глаза!» [Достоевский 1981:223]. Князь думает о том, что Рогожин убьет, он решает это про себя, хотя и сомневается в правомерности такой мысли: «...но... разве решено, что Рогожин убьет?! - вздрогнул вдруг князь. «Не преступление ли, не низость ли с моей стороны так цинически-откровенно сделать такое предположение!» - вскричал он ... Он разом вспомнил и давешний Павловский вокзал, и давешний Николаевский вокзал, и вопрос Рогожину прямо в лицо о глазах, и крест Рогожина, который теперь на нем, и благословение его матери, к которой он же его сам привел, и последнее судорожное объятие, последнее отречение Рогожина, давеча, на лестнице, - и после этого всего поймал себя на беспрерывном искании чего-то кругом себя...» [Достоевский 1981:220]. Князь близит развязку: «Сейчас все разрешится!» - с странным убеждением проговорил он про себя ... Он ступил уже один шаг, но не выдержал и обернулся. Два давешние глаза, те же самые, вдруг встретились с его взглядом. Человек, таившийся в нише, тоже успел уже ступить из нее один шаг. Одну секунду оба стояли друг перед другом почти вплоть. Вдруг князь схватил его за плечи и повернул назад, к лестнице, ближе к свету: он яснее хотел видеть лицо. Глаза Рогожина засверкали, и бешеная улыбка исказила его лицо. Правая рука его поднялась, и что-то блеснуло в ней; князь не думал ее останавливать. Он помнил только, что, кажется, крикнул: Парфен, не верю!.. Затем вдруг как бы что-то разверзлось пред ним: необычайный внутренний свет озарил его душу ... С ним случился припадок эпилепсии» [Достоевский 1981:225-226]. Глаза Рогожина для князя Мышкина знамение неизбежного убийства, невольное впечатление, которое переходит в полное убеждение, что так тому и быть. Князь вызывает и формирует данное видение. Мир вокруг него погружается во мрак, все становится тяжелым, бредовым, сумрачным, князь блуждает в потемках сознания буквально перенося это в реальный мир, в хождение по городу. Он идет, не замечая дороги, мучительно напрягает внимание, всматривается во все, что попадается ему на глаза, небо, Нева... Усиливается эпилептическое состояние и медленно 
надвигается гроза... Князь доводит свое видение до яркости и отчетливости в момент встречи с Рогожиным. И в момент припадка сознание героя гаснет, но к нему приходит иное, высшее видение небесной гармонии. Длится это пару секунд, а потом все погружается во мрак. Перестает видеть князь и перестаем видеть мир его глазами и мы: «Известно, что припадки эпилепсии, собственно самая падучая приходит мгновенно ... искажается лицо, особенно взгляд ... Страшный, невообразимый ... вопль вырывается из груди ... Представляется даже, что кричит как бы кто-то другой, находящийся внутри этого человека ... вид человека в падучей производит решительный и невыносимый ужас, имеющий в себе даже нечто мистическое. Надо предположить, что такое впечатление внезапного ужаса, сопряженного со всеми другими страшными впечатлениями той минуты, вдруг оцепенили Рогожина на месте и тем спасли князя от неизбежного удара ножом, на него уже падавшего» [Достоевский 1981:226]. Видение мира и другого в мире - двойственный «дар». Как уже было отмечено выше, образ Настасьи Филипповны обладает большой силой и завораживает многих, князя Мышкина тоже, но и его видение героини оказывает не менее сильное влияние на саму Настасью Филипповну. Вначале князь по портрету составляет для себя идеальный облик Настасьи Филипповны (образ не только красоты, но и добра), которому позже она пытается соответствовать. Наблюдая за вызывающим поведением Настасьи Филипповны в доме у Гани, князь не выдерживает и восклицает: «А вам и не стыдно! Разве вы такая, какою теперь представляетесь. До может ли это быть! вскрикнул вдруг князь с глубоким сердечным укором ... Я ведь и в самом деле не такая, он угадал, - прошептала она быстро, горячо, вся вдруг вспьхнув $и$ раскрасневшись...» [Достоевский 1981:114]. В дальнейшем влияние князя на душу Настасьи Филипповны усиливается, она всеми силами пытается его разуверить в своем «совершенстве» и в тоже время стремится к свету, который исходит от князя и не чужд ей самой. Но она боится этого света и потому бежит с Рогожины от предложения князя Мышкина. Затем возвращается к князю, и они проводят какое-то время вместе, время мучительное для князя, 
опустошающее, когда вместо любви появляется жалость: «O, я любил ее; $о$, очень любил... но потом... потом... потом она все угадала ... Что мне только жаль ее, а что я.. уже не люблю ее» [Достоевский 1981:418]. Но оставить Настасью Филипповну князь Мышкин не может, это его боль, наваждение, его крест. Над ним сохраняется таинственная власть лица, при виде которого князь теряет всякое самообладание. Перед ее лицом он чувствует свое бессилие и испытывает поистине мистический ужас: «Несколько раз припоминал он в эти шесть месяцев то первое ощущение, которое произвело на него лиц̧о этой женщины, еще когда он увидел ее только на портрете; но даже во впечатлении от портрета, припоминал он, было слишком много тяжелого. Тот месяц в провинции, когда он чуть не каждый день виделся с нею, произвел на него действие ужасное, до того, что князь отгонял даже воспоминание об этом еще недавнем времени. В самом лище этой женщины всегда было для него что-то мучительное ... лицьо это еще с портрета вызывало из его сердца целое страдание жалости» [Достоевский 1981:337]. Настасья Филипповна «помешанная» и князь не в силах разогнать мрак, угнездившийся в ее больной душе. Верное впечатление оставляет лицо Настасьи Филипповны на князя Мышкина - это обреченность, это ужасный и неотвратимый конец - смерть. В образе Настасьи Филипповны все отчетливее вырисовываются трагические и фатальные черты (при каждой новой встрече и во сне князя, где поведение героини напоминает поведение Рогожина, манящего князя посмотреть на труп Настасьи Филипповны, это наложение образов создает видение преступления). «Вглядывание» открывает неотвратимую катастрофу. В образе Настасьи Филипповны и красота, спасающая мир, и красота мнимая, пугающая, губящая (видение Рогожина). Ее физическая гибель следствие развоплощения, одержимости, увиденной или предначертанной взглядом князя. Одновременно с исчезновением героини меркнет сознание князя, в котором угасает особое видение мира, сходит с ума и Рогожин, приобретая молчаливую неподвижность портрета. 
Чрезвычайно пристальное внимание к глазам, взглядам и видению характерно для романа «Идиот». Герои пристально наблюдают друг за другом, постоянно смотрят и всматриваются, что определяет характер их взаимоотношений и восприятие действительности в целом. Роман «Идиот» наполнен зрительными образами, Ф. М. Достоевский создает визуальный мир, в котором все картины порождены сознанием героев. Таким образом, видение в романе приобретает новое измерение, герои одарены даром «глядеть» и «видеть», прозревать, пророчествовать, побуждать к действию взглядом. Душевные глубины других наиболее понятны князю Мышкину, он воспринимает мир через свое особое видение, формируя целостные, идейно значимые образы, которые доступны лишь внутреннему взору других героев и то в моменты особого духовного напряжения. Видение в романе «Идиот»непреложный факт душевной жизни героев, оно символично и многогранно в произведении Ф. М. Достоевского.

\section{БИБЛИОГРАФИЯ}

Терц 2009 - Терц А. В тени Гоголя / А. Терц. - М. : КоЛибри, 2009. $670 \mathrm{c}$.

Мочульский 1995 - Мочульский К. В. Гоголь. Соловьев. Достоевский / К. В. Мочульский. - М. : Республика, 1995. - 607 с.

Бахтин 1972 - Бахтин М. М. Проблемы поэтики Достоевского [Электронный ресурс] / М. М. Бахтин. - Режим доступа : https://studfiles.net/pre view/460715/.

Достоевский 1981 - Достоевский Ф. М. Идиот : роман четырех частях / Ф. М. Достоевский. - М. : Сов. Россия, 1981. - 592 с.

Достоевский 2006 - Достоевский Ф. М. Записке о русской литературе [Электронный ресурс] / Ф. М. Достоевский. - Режим доступа : http://croquis.ru/ 2330.html.

Назиров 2005 - Назиров Р. Г. Специфика художественного мифотворчества Ф. М. Достоевского : сравнительно-исторический подход // Русская классическая 
литература : сравнительно-исторический подход / Р. Г. Назиров. - Уфа : РИО БашГУ, 2005. - С. 189-198. 